\title{
Investigation of Relationship Between Theoretical Practice Course Success and Attendance
}

\author{
Oğuzhan Dalkıran \\ Correspondence: Oğuzhan Dalkıran, School of Physical Education and Sports, Mehmet Akif Ersoy University, Burdur, \\ Turkey.
}

Received: March 25, 2018

doi:10.11114/jets.v6i5.3130

\author{
Accepted: April 21, $2018 \quad$ Online Published: April 25, 2018
}

URL: https://doi.org/10.11114/jets.v6i5.3130

\begin{abstract}
The aim of the study is to determine the relationship between the attendance of theoretical and applied field courses and the success status of the students attending Sports Science Faculty. The data of the study consisted of 68 female and 88 male students in the Faculty of Sports Sciences; two lectures and two practicals, and 624 grade points and 14 weekly course hours. The data were obtained from course attendance schedules of the instructors and transcripts from the academician information system. In the analysis of the data, descriptive statistical analysis in the SPSS (Ver.22) package program, the direction and strength of the relationship between dependent and independent variables in relation by the Pearson product moment correlation analysis, course attendance and academic success test by regression analysis was determined. There was a moderate, positive, and meaningful relationship between attendance and academic achievement $(r=0.528, p<.01)$. There was a moderate, positive and significant relationship between attendance and academic success in both theoretical and applied courses $(\mathrm{R}=0.610, \mathrm{p}<.01, \mathrm{r}=0.575, \mathrm{p}<.01)$. As another result; there is a significant relationship between the predictor variable attendance and the academic success, which is the predictor variable $(\mathrm{r}=0.528$, $\mathrm{p}<.050$ ). According to this result; it can be said that $28 \%$ of the variance related to academic achievement is explained with the attendance.
\end{abstract}

Keywords: theoretical course success, practice course success, course attendance, academic achievement

\section{Introduction}

The most important aim of the schools is to enable the students to learn in the best way and be successful. Effective learning and teaching process is a learning and teaching model that considers the learning environment or content, the characteristics of the student and the teacher, and the teaching cycle that the teacher directs to facilitate instruction (Bos and Vaughn, 2002). One of the most important aims of education is to increase academic success in providing the schools to be successful (Keçeli-Kays1l1, 2008). Success is measured by means of the exams given in order to determine whether the behavioral change determined with the goals as a result of the educational practices is acquired in the desired way and giving the decision in regard to covering the expectations (Yetim, 2006). Success is also one of the most important factors in higher education institutions providing education in this context.

Success in general terms means living in harmony. A successful person reaches his/her goals by means of programs. The successful person has some features such as knowing him/herself, using the time efficiently, evaluating his/her condition objectively, listening and observing, asking for help and setting an objective (Baltaş and Baltaş, 1987). Academic success means the behavioral changes in all program areas except for the individual's psychomotor and emotional development (Erdoğdu, 2006). Since the main aim of education is to provide the behavioral changes of the students in the desired way, it means that the students constitute the focus of these activities. Thus, it is important to reveal the extent to which the behavioral changes in terms of educational aims are realized in the student and what are the basic elements that affect student success (Aydoğdu, 2006).

Considering the fact that either the distance education or the compulsory attendance are frequently examined in higher education (Moore et al., 2003; Gump, 2005), to what extent the face to face education and training activities are important in making difference and creating development has been discussed as a subject worth the pilot survey. In face to face education; students directly communicate with their teachers and are included in the study process. The teacher is in a position that brings the subject and the student together, transfers the subject to student and provides the necessary interaction. Moreover, the general opinion in face to face education is that the best way for the students to provide 
effective learning is the use of different educational practices together by the teacher (Hammen and Kelland, 1994). There are many factors that affect success in face to face education, as well.

In a learning environment, the factors affecting the success have been discussed in different dimensions in literature. Büyüköztürk and Deryakulu (2002), in their studies, concluded that for university students, the variables such as high school graduation grade, social and academic adaptation, university entry score, gender and the living place are the important predictors of academic success. Keçeli-Kaysılı (2008) emphasized that the family factor supports the success at an important level; Wilson (2001) emphasized that motivation is important in learning and success. Polat (2017), Atik (2016) and Mammadov (2015) stated respectively that the followings affect the success levels of the students; anxiety and self-efficacy level; confidence in teacher, attitude toward school, school alienation and school burnout; emotional intelligence. Özbay (1997), on the other hand, determined the factors affecting the success of university students as domestic problems, academic and occupational problems, educational backgrounds, depression, relationships of the students with people and their behaviors of asking for help. Senemoğlu (1990), Rençber (2012), Yaşar and Balkıs (2004) and Kaplan (2009) said in their studies that one of the most important factors affecting the success at schools is the absence from school. Absence factor is one of the undesirable behaviors that negatively affect the attitude both toward learning and toward school.

School absenteeism is an undesirable student behavior that can stem from many factors such as physical, psychological and social, and is thought to negatively affect the success of the student (Milli Eğitim Müdürlüğ̈̈ [MEM], 2013). Looking at the studies conducted, many reasons of absenteeism have been discussed. These reasons have been addressed as the decline of interest in school, decreased motivation, instructors, course contents, social activities, unexpected situations, transportation problems, decline in course success, problems about the students themselves, their environments and families, school environment, and school management (Şimşek, Uğurlu and Usta, 2016; Şanl, Altun and Çetin, 2015; Apay and Eryılmaz, 2011).

Continuous absence of the students from lessons results in falling behind their friends, having difficulty in understanding the course contents, decrease in the academic success and delay in graduation or total dropout (Jerald, 2006).

In addition, it should be considered that course attendance or face to face education contributes to social development of the student as well as the academic success, the ability to respect the differences, critical thinking, analyzing and discussing skills significantly; in other words, they are important in terms of being a socially beneficial individual meeting the expectations of the society. Accordingly; this research aims to determine the relationship between the attendance of the students studying in the school of physical education and sports to theoretical and applied field courses and their academic standing regarding the courses, and the predictiveness.

\section{Method}

\subsection{Research Model}

In the research, out of the relational research methods, correlational method was used. Correlational researches are the researches conducted in order to describe the relationships between two or more variables and analyzing the relationships thoroughly (Tanrı̈ğgen, 2011).

\subsection{Study Group}

Study data were collected from 68 females, 88 males, a total of 156 students; two theoretical, two practical, total of four field courses taken from the notes (624 in total) and the course hours that they have formed in 14 weeks.

\subsection{Data Collection}

The data were obtained from the course attendance schedules of two lecturers and transcripts from the academicians' information system.

\subsection{Data Analysis}

In the analysis of the data, descriptive statistical analysis in the SPSS (Ver.22) package program, the direction and strength of the relationship between dependent and independent variables in relation by the Pearson product moment correlation analysis, course attendance and academic success test by regression analysis was determined. In the analyses made, the significance level was accepted as 0.05 .

\section{Findings}

It is detected that there was a moderate, positive, and meaningful relationship between attendance and academic achievement $(r=0.528, p<.01)$; there was a moderate, positive and significant relationship between attendance and academic success in both theoretical and applied courses according to the course variable $(r=0.610, p<.01, r=0.575$, $\mathrm{p}<.01$ ); while there was not a significant correlation between course attendance and academic success according to the 
gender variable. As another result; there is a significant relationship between the predictor variable attendance and the academic achievement, which is the predictor variable $(r=0.528, \mathrm{p}<.050)$.

Table 1. Regression Analysis Results in regard to Predicting Academic success with Course Attendance

\begin{tabular}{llllll}
\hline Variable & $\mathrm{B}$ & $\begin{array}{l}\text { Standard } \\
\text { ErrorB }\end{array}$ & $\mathrm{B}$ & $\mathrm{t}$ & $\mathrm{p}$ \\
\hline Academic success & 18,137 & 5,862 & - & 3,094 & .002 \\
Attendance & 1,151 &, 149 &, 528 & 7,708 & .000 \\
\hline $\mathrm{R}=0.528$ & $\mathrm{R} 2=0.278$ & & $\mathrm{~F}=59,408$ & $\mathrm{p}=.000$ &
\end{tabular}

According to the analysis results; there is a significant relationship between the predictor variable course attendance and the dependent variable academic success $(r=0.528, \mathrm{p}<.050)$. According to this result; it can be said that $28 \%$ of the variance related to academic achievement is explained with the attendance. As a result, it can be said that the course attendance is a significant predictor of academic success.

Table 2. The Relationship Between Course Attendance and Academic success

\begin{tabular}{llll}
\hline \multirow{2}{*}{ Variable } & & $\begin{array}{l}\text { Course } \\
\text { Attendance }\end{array}$ & $\begin{array}{l}\text { Academic } \\
\text { success }\end{array}$ \\
\hline \multirow{3}{*}{ Course Attendance } & Pearson Correlation & 1 &, $528^{* *}$ \\
\cline { 2 - 4 } & Sig. (2-tailed) & 156 &, 000 \\
\cline { 2 - 4 } Academic success & $\mathrm{n}$ &, $528^{* *}$ & 156 \\
\hline \multirow{3}{*}{ Pearson Correlation } &, 000 & 1 \\
\cline { 2 - 4 } & Sig. (2-tailed) & 156 & 156 \\
\cline { 2 - 4 } & $\mathrm{n}$ & & \\
\hline
\end{tabular}

It is detected that there was a moderate, positive and significant correlation between course attendance and academic success $(r=0.528, p<.01)$. According to this finding; it can be said that the higher the course attendance the higher the academic success becomes $(\mathrm{r} 2=0.28)$.

Table 3. The Relationship Between the Course Attendance and Academic success According to the Theoretical and Applied Course Variable

\begin{tabular}{|c|c|c|c|c|}
\hline & Variable & & $\begin{array}{l}\text { Course } \\
\text { Attendance }\end{array}$ & $\begin{array}{l}\text { Academic } \\
\text { success }\end{array}$ \\
\hline \multirow{6}{*}{ Theoretical } & \multirow{3}{*}{ Course Attendance } & Pearson Correlation & 1 &, $610 * *$ \\
\hline & & Sig. (2-tailed) & &, 000 \\
\hline & & $\mathrm{n}$ & 80 & 80 \\
\hline & \multirow{3}{*}{ Academic success } & Pearson Correlation & ,610** & 1 \\
\hline & & Sig. (2-tailed) &, 000 & \\
\hline & & $\mathrm{n}$ & 80 & 80 \\
\hline \multirow{6}{*}{ Application } & \multirow{3}{*}{ Course Attendance } & Pearson Correlation & 1 & ,575** \\
\hline & & Sig. (2-tailed) & & 000 \\
\hline & & $\mathrm{n}$ & 76 & 76 \\
\hline & \multirow{3}{*}{ Academic success } & Pearson Correlation &, $575 * *$ & 1 \\
\hline & & Sig. (2-tailed) &, 000 & \\
\hline & & $\mathrm{n}$ & 76 & 76 \\
\hline
\end{tabular}

It is detected that there was a moderate, positive and significant correlation between theoretical course attendance and academic success $(r=0.610, p<.01)$; a moderate, positive and significant correlation between applied course attendance and academic success $(r=0.575, \mathrm{p}<.01)$. According to this finding; it can be said that the higher theoretical and applied course attendance the higher the academic success becomes ( $\mathrm{r} 2=0.37, \mathrm{r} 2=0.33$ ).

\section{Conclusion and Discussion}

As a result; while there was not any significant correlation between the course attendance and academic success according to the gender variable, there was a significant correlation either between the course attendance and academic success or between the course variable and academic success. As a similar result; Altınkurt (2008) in the study on the relationships between high school students' absence and their academic success detected that there was a negative and moderate correlation between the absence without excuse and academic success. According to Yaşar and Belkis (2004), discontinuance of the students' attendance and being late to lessons lead to incomplete learning, which in turn negatively affects the success of the students in the relevant lesson. For this reason, it is important to reduce students' absenteeism for the classes. Senemoğlu (1990) concluded that out of the characteristics of teaching-learning process, course attendance duration is the most powerful predictor of the learning level. As a result of the research by Rençber (2012), it is concluded 
that there is a strong relationship between the student success and the number of attendance.

In literature; there are studies in regard to the fact that course absenteeism negatively affects academic success (Park and Kerr, 1990); course attendance can affect the success, but it is not an essential factor (Hammen and Kelland, 1994); there is a high relationship between course attendance and academic success, but the otherwise also happens (Moore et al., 2003). Koppenhaver (2006) stated that participation of the student in the class is not the only variable of success, besides this, active or passive, voluntarily or compulsory attendance of the students, student or teacher centered course are also among the variables affecting the learning success. In order to have a high correlation between attendance and success, the quality of teaching must be high. On the other hand, this degree of correlation may also vary according to the natural structure of the course content. While the students are learning certain course contents might need the help of teacher more than the other course contents (Kablan, 2009).

It can be said that the same rate of moderate and positive relationship between theoretical and applied courses and academic success indicates the fact that there are also other factors in academic success (Gump, 2005), difference in talent level, branch disposition, previous teaching process.

On the other hand: active or passive, voluntarily or compulsory course attendance of the students, student or teacher centered course are also among the variables affecting the learning success (Koppenhaver, 2006). Similarly; it is necessary to study to what extent forcing the students to attend the course by means of transferring the book information to the course as it is is effective in terms of learning and to observe the results (Browne, Hoag and Wheeler, 1994). Therefore; while the schools are determining the rules regarding attendance, it should be expected that these rules should not only increase the attendance but also increase the performance of the student (Mora, 1997).

As a result; it should be kept in mind that course attendance provides positive contribution either to academic success or effective learning and socializing processes, but as well as course attendance, the real success will be obtained by providing the learner to actively participate in learning in terms of an effective teaching process.

\section{References}

Altınkurt, Y. (2008). The reasons for students irregular attendance and the effect on this students irregular attendance on their academic achievement, Journal of Dumlupinar University Social Sciences, 20, April, 129-142.

Apay, A., \& Eryılmaz, A. (2011). Investigation of the relationship between high school students' motivation to class engagement and school burnout. Mehmet Akif Ersoy Üniversitesi Eğitim Fakültesi Dergisi, 1(21), 25-44.

Atik, S. (2016). Teacher confidence as predictors of academic success, attitude towards the school, alienation of the school, and school burnout (Unpublished doctoral dissertation), İnönü University Educational Sciences Institute, Malatya.

Baltaş, A., \& Baltaş, Z. (1987). Stres ve Başa Çıkma Yolları. İstanbul: Remzi Kitabevi.

Bos, C. S., \& Vaughn, S. (2002). Strategies for teaching students with learning and behavior problems. (5th ed.). USA: Allyn and Bacon.

Browne, N., Hoag, J., \& Wheeler, M. (1994). Correspondence. Journal of Economic Perspectives, 8, 211-213. https://doi.org/10.1111/j.1365-2222.1994.tb00974.x

Büyüköztürk, Ş., \& Deryakulu, D. (2002). The factors affecting the computer education and instructional technologies teacher program and the classroom teacher program students' academic achievements. Educational Management in Theory and Practice, 30, 187-204.

Erdoğdu, Y. M. (2006). Relationships between creativity, teacher behaviours and academic success. Electronic Journal of Social Sciences, 5(17), 95-106.

Gump, S. E. (2005). The cost of cutting class: Attendance as a predictor of success. College Teaching, 53(1), 21-26. https://doi.org/10.3200/CTCH.53.1.21-26

Hammen, C. S., \& Kelland, J. L. (1994). Attendance and grades in a human physiology course. The American Journal of Physiology, 12(1), 105-108. https://doi.org/10.1152/advances.1994.267.6.S105

Jerald, C. D. (2006). Identifying potential dropouts: key lessons for building an early warning data system. American Diploma Project Network.

Kablan, Z. (2009). The effects of attendance on teacher candidates' learning. Pamukkale University Journal of Education, 1(25), 22-32.

Keçeli-Kaysıll, B. (2008). Family involvement in increasing academic achievement. Ankara University Faculty of Educational Sciences Special Education Journal, 9(01), 069-083. https://doi.org/10.1501/Ozlegt_0000000115 
Koppenhaver, G. D. (2006). Absent and accounted for: Absenteeism and cooperative learning. Decision Sciences Journal of Innovative Education, 4, 29-49. https://doi.org/10.1111/j.1540-4609.2006.00100.x

Mammadov, E. (2015). Relationship between emotional intelligence and academic achievement: research on undergraduate tourism students. Unpublished master's thesis, Adnan Menderes University Social Sciences Institute, Aydin.

Marburger, D. R. (2001). Absenteeism and undergraduate exam performance . Journal of Economic Education, 32(2), 99-109. https://doi.org/10.1080/00220480109595176

MEM, (2013). Action plan to increase student attendance rates for secondary education institutions. Giresun Governorship National Education Pirectorate http://trg.docdat.com/tw_files2/urls_65/6/d-5631/7z-docs/1.pdf erişim: 18/12/2013

Moore, R., Jensen, M., Hatch, J., Duranczyk, I., Staats, S., \& Koch, L. (2003). Showing up: The importance of class attendance for academic success in introductory science courses. The American Biology Teacher, 65(5), 325-329. https://doi.org/10.2307/4451508

Mora, M. (1997). Attendance, schooling quality, and the demand for education of MexicanAmericans, African Americans, and non-Hispanic whites. Economics of Educaiton Review, 16(4), 407-418. https://doi.org/10.1016/S0272-7757(96)00064-7

Özbay, G. (1997). A scale development validity and reliability study to determine problem areas of university students, published master's thesis. Karadeniz Teknik University Social Sciencecs Institute, Trabzon.

Park, K. H., \& Kerr, P. M. (1990). Determinants of academic performance: A multinomial logit approach. The Journal of Economic Education, 21(2), 101-111. https://doi.org/10.1080/00220485.1990.10844659

Polat, A. G. E. (2017). Academic achievement and its relationship with anxiety level and academic self-efficacy. Journal of Management and Economics Research, 15(Additional issue), 1-22.

Rençber, B. A. (2012). The factors affecting university students' academic achievement. Journal of Çankırı Karatekin University Social Sciencecs Institute, 3(1), 191-198.

Şanlı, Ö., Altun, M., \& Çetin, T. A. N. (2015). Examining the reasons for students being absent from schools in accordance with the views of the students who are absent from their schools. Electronic Journal of Social Sciences, 14(55), 161-177.

Senemoğlu, N. (1990). Strengths to determine the level of learning in mathematics classes of student input qualifications and teaching-learning process characteristics. Hacettepe University Journal of Education, 5(5), 259-270.

Şimşek, A. S., Uğurlu, C. T., \& Usta, H. G. (2016). Determination of absenteeism tendency of university students: scale development study. Ahi Evran University Journal of Kırşehir Education Faculty (KEFAD), 17(1), 297-311.

Wilson, J. (2001). Increasing Student Motivation through the Use of Instructional Strategy. ERIC Document Reproduction Service No. ED455962.

Yaşar, M., \& Balkıs, M. (2004). Investigatting the causes of academic failure among students that attends summer course at faculty of education in pamukkale university. Pamukkale University Journal of Education, 15(1), 88-106.

Yetim, H. (2006). The relationship between the attitudes of 8th grade primary school students towards mathematics and turkish lectures and the successes of these courses (Published doctoral dissertation), Dokuz Eylül University Education Sciences Institute, İzmir.

\section{Copyrights}

Copyright for this article is retained by the author(s), with first publication rights granted to the journal.

This is an open-access article distributed under the terms and conditions of the Creative Commons Attribution license which permits unrestricted use, distribution, and reproduction in any medium, provided the original work is properly cited. 